\title{
Strategic Management in Development of Youth and Women Entrepreneurship - Case of Serbia
}

\author{
Ivan Todorović ${ }^{1}$, Stefan Komazec ${ }^{1}$, Miloš Jevtić ${ }^{1}$, Vladimir Obradović ${ }^{1}$, Miha Marič \\ 1 University of Belgrade, Faculty of Organizational Sciences, Serbia \\ Jove llića 154, 11000 Belgrade, Serbia \\ ivan.todorovic@fon.bg.ac.rs, stefan.komazec@fon.bg.ac.rs, milos.jevtic@fon.bg.ac.rs, \\ vladimir.obradovic@fon.bg.ac.rs \\ ${ }^{2}$ University of Maribor, Faculty of Organizational Sciences, Slovenia \\ Kidričeva cesta 55a, 4000 Kranj, Slovenia \\ miha.maric@fov.uni-mb.si
}

\begin{abstract}
Background and Purpose: Volume and sophistication of scientific research related to different aspects of entrepreneurship have significantly increased in recent years. Many authors point out the positive influence that development of micro, small and medium enterprises and entrepreneurship has on economic growth and job creation. According to various researchers, youth entrepreneurship and women entrepreneurship are two very important elements of this global phenomenon. The purpose of this paper is to provide the analysis of strategic framework for the support to the development of youth and women entrepreneurship in Serbia.

Design/Methodology/Approach: Situational analysis of youth and women employment and examination of official Government strategic documents related to strategic framework for the support to the development of youth and women entrepreneurship in Serbia will be conducted.

Results: Concrete activities have to be performed by different stakeholders, mostly non-government organizations. The activity stakeholders are on the bottom of the institutional framework, which provides the support to MSME (Micro, Small and Medium Enterprises) sector that will execute the operations in accordance with the defined strategic framework.

Conclusion: Youth-run enterprises provide numerous benefits for society; they reduce youth unemployment and help young people prepare for their future. Female entrepreneurs also have strong economic and social impact.
\end{abstract}

Keywords: entrepreneurship; micro small and medium enterprises; MSME sector; entrepreneur; women; strategy; strategic management

\section{Introduction}

Considering the strategic role that entrepreneurship has in economic development (Baptista and Thurik, 2007), research area of this phenomenon has been widened significantly in recent years, providing increased number of scientific papers related to different aspects of this topic (Kreiser, Marino and Weaver, 2002; Landstrom, Harirchi and Ăstrom 2012; Uyar and Deniz, 2012). Positive influence of entrepreneurship on acceleration of economic ac- tivities and GDP growth (Wennekers and Thurik, 1999), as well as its potential for job creation (Thurik, Carree, van Stel and Audretsch, 2008), influenced researchers from different fields to pay more attention to this subject. It is necessary to emphasize the importance of micro, small and medium enterprises (MSME) and entrepreneurship development in country economy (Todorović, Komazec, Jevtić and Pintar, 2016). A positive relationship can be identified between the relative size of the MSME sector and economic growth (Beck, Demirguc-Kunt and Levine, 
2005). The experience of countries with developed market economies shows that solving socio-economic problems depends largely on the level of development of MSME (Micro, Small and Medium Enterprises) category enterprises (Ratanova, Reshina, Bruna, and Gross, 2014). Their major role is accelerating the economic growth and alleviating consequences of structural unemployment through self-employment of the unemployed (Płaziak and Rachwał, 2014). Development of MSME can directly influence the country opportunities to participate in world economical processes (Acs, Morck and Yeung, 1997).

Special attention is given to development of MSME in transitional and developing countries, which are facing major challenges in terms of tackling high unemployment and unequal distribution of earnings (Erić, Beraha, Đuričin, Kecman and Jakšić, 2012). Government support programs are crucial for development of MSME sector (Komazec, Todorović and Jevtić, 2016). The authorities at various levels has the option to solve identified problems in the MSME sector by using appropriate government programs (Audretsch, Keilbach, and Lehmann, 2006), and the role of governments should be facilitative, not dictatorial, in order to achieve the intended results (Wilson, 2007).

As it was explained previously, due to the comprehensiveness of the subject and its huge influence on economic growth, different issues related to the entrepreneurship are constantly being researched by various authors. Two very important issues are youth entrepreneurship (Chigunta, 2002) and women entrepreneurship (De Bruin, Brush and Welter 2007). This paper aims to provide situational analysis of youth and women employment and entrepreneurship in Serbia and the overview of the strategic government plans for their development, as well as to identify key aspects that have to be approached carefully during the strategy implementation phase. Second chapter will emphasize the importance of youth and women entrepreneurship and give theoretical background, paragraph three will explain the research methodology, section four will present situational analysis, while in fifth will be described adopted strategic framework for the developments of youth and women entrepreneurship in Serbia. Final chapter will present our conclusions and directions for further research.

\section{Literature Review}

This paragraph will provide the review of the scientific literature and previous research related to the phenomena of youth entrepreneurship and women entrepreneurship, in order to present their social and economic influence and to emphasize the importance of strategic management in development of youth and women entrepreneurship at country level.

\subsection{Youth entrepreneurship}

Youth unemployment is one of the major economic and social issues worldwide. Youth development and empowerment are vital stages in life for building the human capital that allows young people to avoid poverty and lead better, and possibly have a more fulfilling life (Awogbenle and Iwuamadi, 2010). Long spells of unemployment in early age can have serious long-term effects for individuals, such as reduced earnings and social exclusion (OECD, 2012). According to Gregg and Tominey (2005), single year of unemployment during youth can reduce annual earnings at age 42 by up to $21 \%$. Additionally, it is estimated that and that additional three months of unemployment prior to the age of 23 results in an extra two months of unemployment, on average, between the ages of 28 and 33 (Gregg, 2001).

Self-employment and entrepreneurship can provide career options for young people by unleashing their economic potential (UNIDO, 2016). Entrepreneurship development is increasingly accepted as an important mode of technical assistance and a useful alternative for income generation among young people (Ryan, 2003). Youth entrepreneurship can be defined as the practical application of enterprising qualities, such as initiative, innovation, creativity, and risk-taking into the work environment, using the appropriate skills necessary for success in that environment and culture (Schnurr and Newing, 1997). The human capital formed in youth is an important determinant of long term growth and poverty reduction on national level (Awogbenle and Iwuamadi, 2010). Youth-run enterprises (YREs) provide valuable goods and services to society, especially the local community (Chigunta, 2002). Aspiration towards self-employment should be developed in early period, since ageing has unfavorable impact on entrepreneurial activity (Troha Akanni and Čepar, 2015). Considering the significant effect of entrepreneurship and self-employment on generating new jobs and economic growth, promotion of youth entrepreneurship and strategic support to YRE creation and development is of huge importance for every country.

\subsection{Women entrepreneurship}

Since Schwartz (1976) published the first important scientific paper related to women entrepreneurship, it has become interesting topic for many researchers, and the recognition of its significance to development of entrepreneurship has widely increased (Revenga and Shetty, 2012). However, in most cultures there is a strong division between male and female roles (Duflo, 2012). When we look at the world population, there are more women than men, but female employment is lower than male employment, and their salaries are usually inferior (Mitchelmore and Rowley, 2013). Additionally, women are rarely on executive positions (Zlatkov Cvetković, 2015), they are 
often excluded from decision-making (Pines, Lerner, and Schwartz, 2010) and, compared to men, they have less opportunity to control their lives (Revenga and Shetty, 2012).

However, many women have the adequate level of creativity, expertise and skills necessary to start and run a business, but often do not have equal access to finance, education and information as male entrepreneurs, which are required for successful business management (Witbooi and Ukpere, 2011). Besides gender discrimination, additional obstacle for women to become entrepreneurs is their engagement in the households and with children (Vossenberg, 2013). Despite all barriers, there are bright examples of women with different backgrounds who have entered the private business and founded a MSME (Alam, Senik and Jani, 2012). Factors of motivation for women to start a new business can be various (Kalyani and Kumar, 2011), but the main reasons are usually to ensure family existence and the aspiration to prove their own abilities (Gidarakou, 2015). Their engagement in entrepreneurship is highly personalized and they often bring their personality and values into the business (Rey-Marti, Tur Porcar and Mas-Tur, 2015).

Female entrepreneurship has been recognized as an important source of economic growth (Duflo, 2012). It also has a strong impact on achieving gender equality, democratization and development of society, the preservation of peace and poverty reduction (Sarfaraz, Faghih and Majd, 2014). Women entrepreneurs create new jobs for themselves and others and by being different also provide society with different solutions to management, organization and business problems as well as to the exploitation of entrepreneurial opportunities (Kokotović, Rakić and Kokotović, 2016). Nevertheless, this mechanism has not been fully utilized, especially in developing countries (Minniti and Naudé, 2010). In order to reach its potential, women entrepreneurship needs strong support and promotion from policy makers and government institutions (OECD, 2004).

\section{Research methodology}

We used the official statistical data to explore current situation when it comes to youth and women employment in Serbia and to compare it with EU countries. Through the interviews with the representatives of the youth and women business infrastructure in Serbia, which includes business incubators and accelerators, business associations and clusters of youth and women, NGOs and civil society organizations, we identified key problems for young people and female in Serbia to start and run their own business. Then we examined official strategies and action plans of Serbian Government regarding the entrepreneurship of youth and women, in order to understand and present institutional framework for its development, as well as strategic management in this area. Finally, we gave our conclusions based on the analysis whether all the identified issues related to the youth and women entrepreneurship in Serbia have been identified and managed in the government strategic framework

\section{Overview of youth and women employment in Serbia}

According to the Statistical Office of the Republic of Serbia (2014), Serbia has significantly higher unemployment rate of younger population comparing to total population. For the population aged 15-24, the unemployment rate is $47.1 \%$, compared to $19.7 \%$ for the working age population. By region, the comparison of youth and total unemployment rate is shown in Figure 1. There is a huge gap in youth unemployment rate between EU and Serbia. The 2013 statistics provided by the Ministry of Youth and Sports, Republic of Serbia (2015) show that the youth unemployment rate in the EU was $23.4 \%$ for young people aged 15-24, while in August 2014 the youth unemployment rate in Serbia was $41.7 \%$ for young people aged between 15 and 24 and $33.27 \%$ for young people aged between 15 and 30 .

Besides the lack of professional experience and practical training, which can be an aggravating factor in the decision to start the business, young people face the problem of underdeveloped entrepreneurial skills as a result of the lack of adequate educational programs in secondary schools and universities, designed to encourage development of entrepreneurship among young people. According to the annual surveys on barriers to business growth, conducted by the Serbian Union of Employers (2013), the lack of adequate staff is nearing the top of the list: from the $8^{\text {th }}$ place in 2006 to the $3^{\text {rd }}$ place in 2013. This is a clear indication that it has become increasingly difficult for the corporate sector to find quality staff; although the corporate sector funds the education system in Serbia through the tax system, employers must invest additional funds in training their staff, instead of using these resources in other areas of business development.

The unemployment rate in Serbia is the highest for the age 15-24, but more growing problem is the inactivity rate of young population. According to the definition used by the Statistical Office of the Republic of Serbia (2014), it refers to the individuals who are not employed and who are not actively looking for a job (in the last month have not taken any steps to find a job). The activity rate for young people in the labour market in Serbia is very low. The activity rate of young people aged 15 to 24 was $28 \%$. This rate is far lower than in the EU Member States 15-24, where over $40 \%$ of young people participate actively in the labour market. The reasons for the low participation rate among young people in the labour market are: disposal operation for purposes of study; low rate of women participation; inadequate qualifications or inadequate ed- 


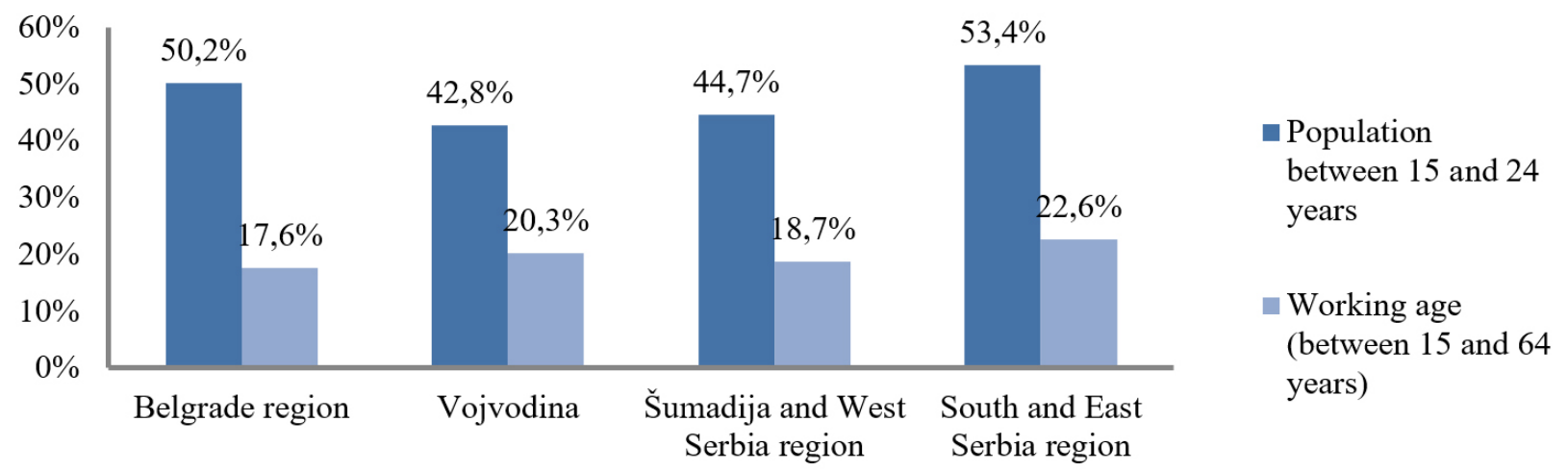

Figure 1: Youth and total unemployment rate in Serbia by region

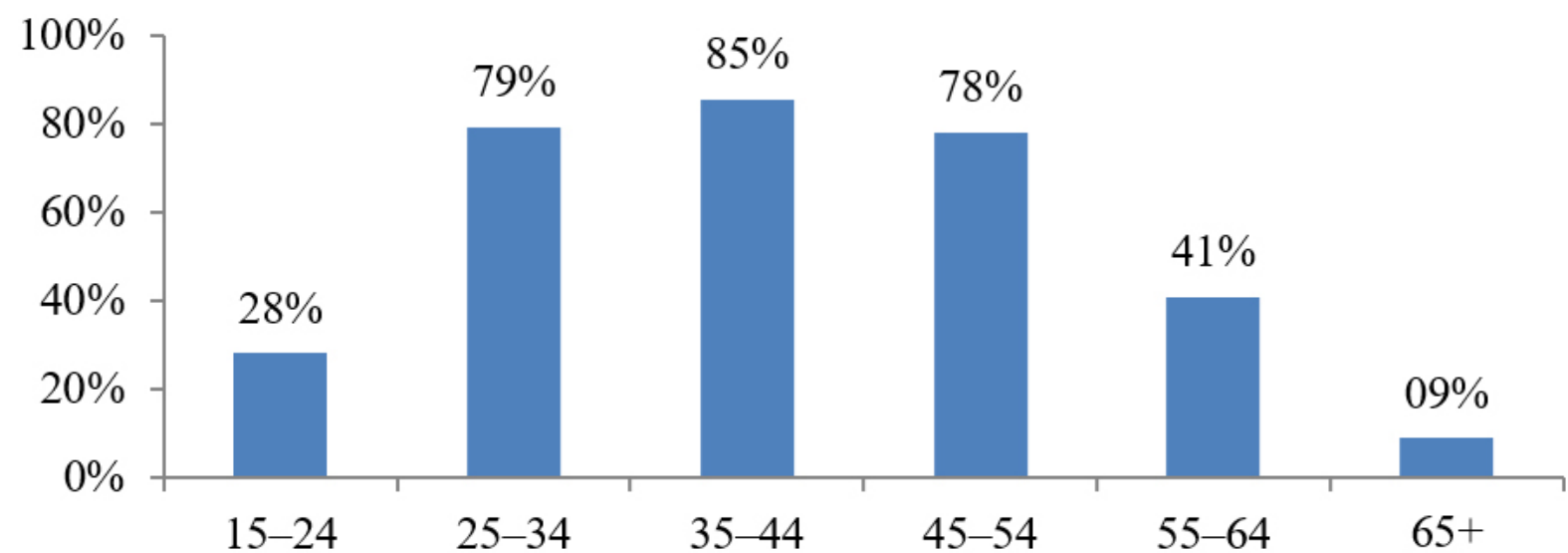

Figure 2: Activity rate of Serbian population by age

ucation for those who have not acquired during schooling or dropped out, but did not establish a connection with the labour market; belonging to rural areas. Activity rate of Serbian population by age is presented in Figure 2.

So, if we look at the young generation, starting from teenagers to more mature age, the situation is changing. In the group of young people up to 19 years in the labour market is active only $10.9 \%$ of persons, in the age group of 20 to 24 years $44.9 \%$, while the percentage of active young people in the group from 25 to 29 years is $75.6 \%$. Overall, the activity rate of young people aged 15 to 29 years was $44.8 \%$, versus $48.4 \%$ for the overall work force.

Particularly favorable picture of the status of young people on the labour market gives an employment rate that is far lower than the average for the active population. Specifically, in 2014 the employment rate of young people (15 to 29 years) was only $26.2 \%$, with a particularly low employment rate of young women $(20.2 \%)$. The employment rate of the working age population in the Republic of Serbia amounted to $37.7 \%$. This tendency is accompanied by a disturbing unemployment rate of 15-29 which in 2014 amounted to $18.6 \%$, while at the same time $17.7 \%$ of women of working age 15-29 were unemployed. Given the failure of the formal educational system with the needs of the labour market, young people are very difficult to find a job regardless of the achieved level of formal education. In fact, most of the young long-term unemployed, with nearly $4 / 5$ of young people wait for employment for more than 24 month. Also, a very high influx of young people into the labour market, who are first-time job seekers, contribute to the growth of the national unemployment rate.

Most young people based their first employment with the employer, so that $79 \%$ of young people work for pay, while a significantly smaller number of those who opt for self-employment (11\%), and the rest helps their household members either in agricultural production, either in actions. Broken down by gender, the situation is somewhat different, since a higher percentage of young women seeking a safe job, choose to work for the employer, while a very small percentage of women have a tendency towards self-employment $(5.6 \%)$. Presented data refer to the fact that the female population is much less interested in activating and finding employment. Differences between the percentage of inactive men and women in Serbia by region 


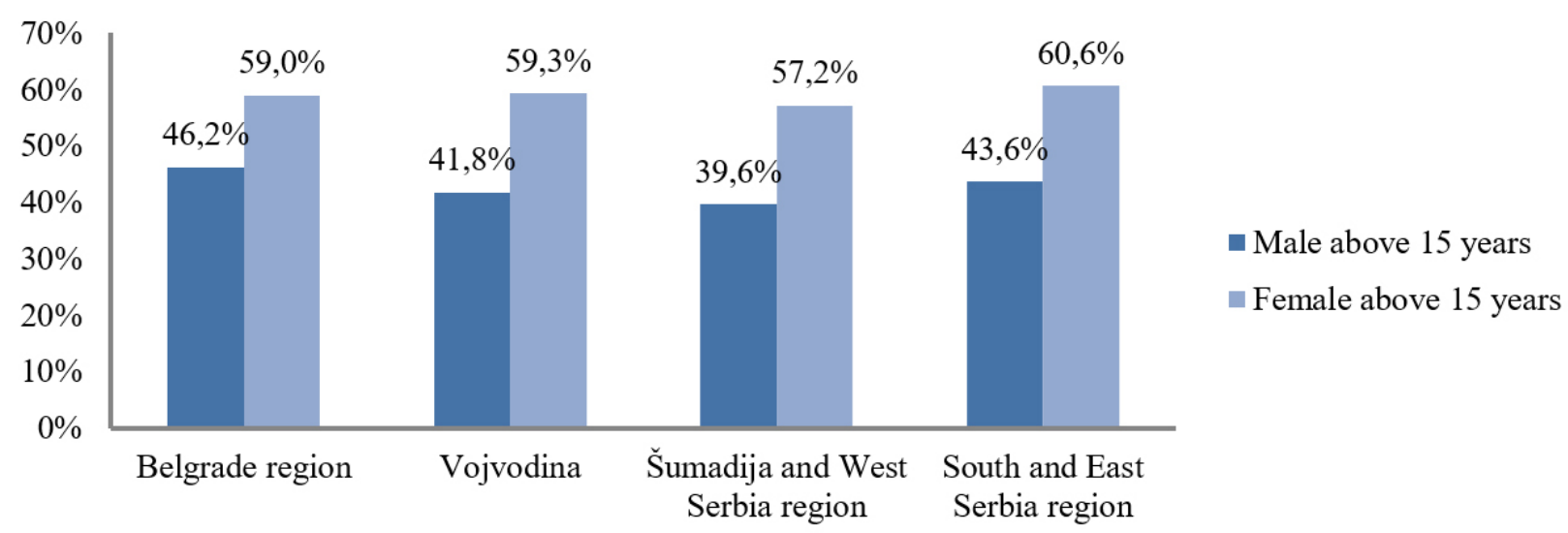

Figure 3: Male and female inactivity rate in Serbia

are presented in Figure 3 (Ministry of Youth and Sports, Republic of Serbia, 2015).

Of all inactive persons who do not seek a job because of childcare or incapacitated adult care, 97\% are women, of which 54\% are aged 15-34. Young women account for one half of young people in Serbia and their position is different from the position of young men, including in the labour market. According to Commissioner for Protection of Equality, Republic of Serbia (2013), young women are exposed to discrimination in employment much more, primarily because of childbirth, but they are also exposed to sexual harassment. However, in Serbia, there is no strategy that is directly and exclusively focused on development of women's entrepreneurship, although the importance of women entrepreneurship is clearly indicated in several official documents, such as The national strategy for improving and promoting gender equality in the Republic of Serbia (Ministry of Labour, Employment, Veteran and Social Policy, Republic of Serbia, 2009), Action plan for the implementation of the National strategy for improving and promoting gender equality 2010 to 2015 (Ministry of Labour, Employment, Veteran and Social Policy, Republic of Serbia, 2010), and The national employment strategy for the period 2011-2020 (Ministry of Labour, Employment, Veteran and Social Policy, Republic of Serbia, 2011). Based on information available from multiple sources, it is clear that the economic potential of women in Serbia is not used enough, either as a business owner or as a workforce (Vrbanac, Milovanović and Perišić, 2016).

\subsection{Key problems for youth and women to start their own business}

According to Chigunta (2002), usual critical areas for development and promotion of youth and women entrepreneurship are following:

- Access to micro-credit for young people,
- Training and business development services,

- Information and marketing,

- Policies and institutional intermediation,

- Financing youth enterprise development and research.

Besides these global issues that were confirmed during our research youth and women entrepreneurship in Serbia also have certain specific threats, such as brain drain, national culture and corruption (Todorović, Komazec, Jevtić and Pintar, 2016). Brain drain refers to the fact that young experts are constantly leaving Serbia. During the last decade of the $20^{\text {th }}$ century and the first decade of the $21^{\text {st }}$ century, more than 40.000 people emigrated from Serbia to North America and EU countries (Grečić, 2010). Turbulences in the last two decades also influenced the culture of Serbian people, who now difficulty accept risk, which is necessary for becoming an entrepreneur. And high level of corruption in Serbia causes the obstacles for youth and women to have adequate institutional support and equal treatment, especially when it comes to government subventions and grants for entrepreneurs.

During the interviews with the representatives of the youth and women business infrastructure in Serbia, following problems of young and female entrepreneurs were pointed out:

- Access to finance,

- Lack of entrepreneurial skills in university curriculums,

- Insufficient institutional support and specialized programs.

Governments can help young entrepreneurs by securing a supportive infrastructure that can help overcome barriers associated with lack of networks, skills, finance for premises and access to associated start-up support (OECD, 2012). In next section will be presented and analyzed the infrastructure and strategy for development of youth and women entrepreneurship in Serbia. 


\section{Strategic and institutional frame- work for development of youth and women entrepreneurship}

Authorities in Serbia have recognized the importance of investing in development of entrepreneurship. The strategy for support to the development of SME, entrepreneurship and competitiveness from 2015 to 2020 was prepared by the Ministry of Economy (2014) and adopted by the Serbian Government. Furthermore, the Ministry of Economy (2015) also developed Action plan for the implementation of the strategy for support to the development of SME, entrepreneurship and competitiveness from 2015 to 2020. In accordance with this action plan, in May 2015 Government of the Republic of Serbia established the Council for
SME, entrepreneurship and competitiveness, as an occasional working body of the Government, whose members are representatives of relevant ministries, representatives from the industry and other interested parties. The main duty of the Council is to monitor and coordinate the implementation of The strategy for support to the development of SME, entrepreneurship and competitiveness from 2015 to 2020, but it also provides suggestions, opinions, initiatives and professional explanations and initiates the activities related to cooperation between different ministries, as well as the ministries and other organizations and institutions related to MSME sector. Institutional framework for MSME development in Serbia, defined by the Ministry of Economy, Republic of Serbia (2015) and adopted by the Government, is presented on following Figure 4.

Youth and women entrepreneurship was given a spe-

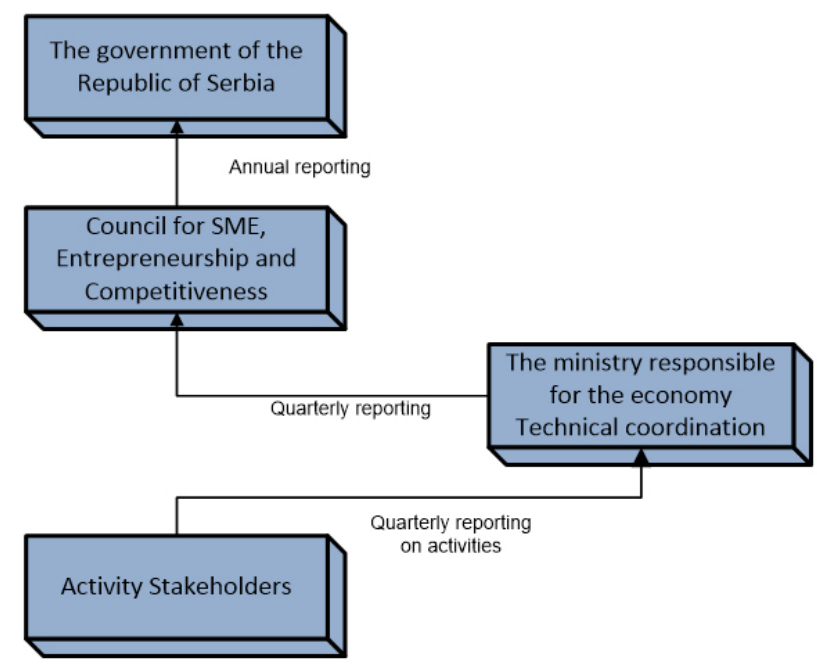

Figure 4: State institutions, which provide support to MSME sector in Serbia

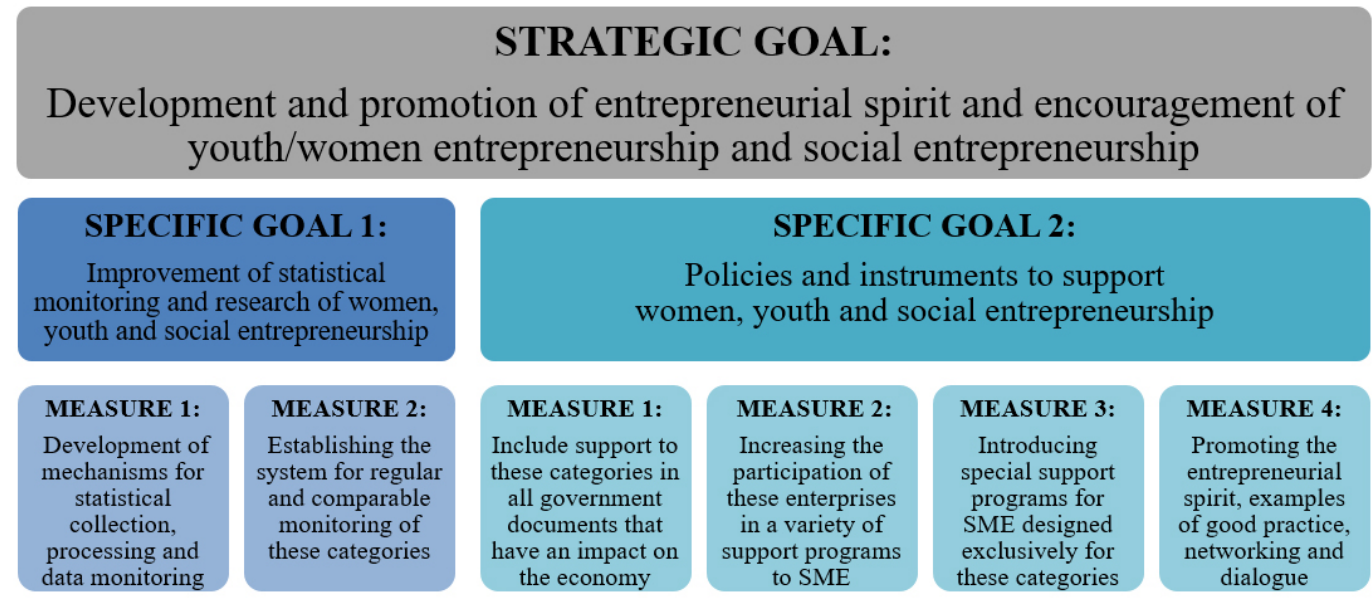

Figure 5: Strategic framework for development of youth/women entrepreneurship in Serbia 


\section{STRATEGIC GOAL:}

\section{Employability and employment of young women and men}
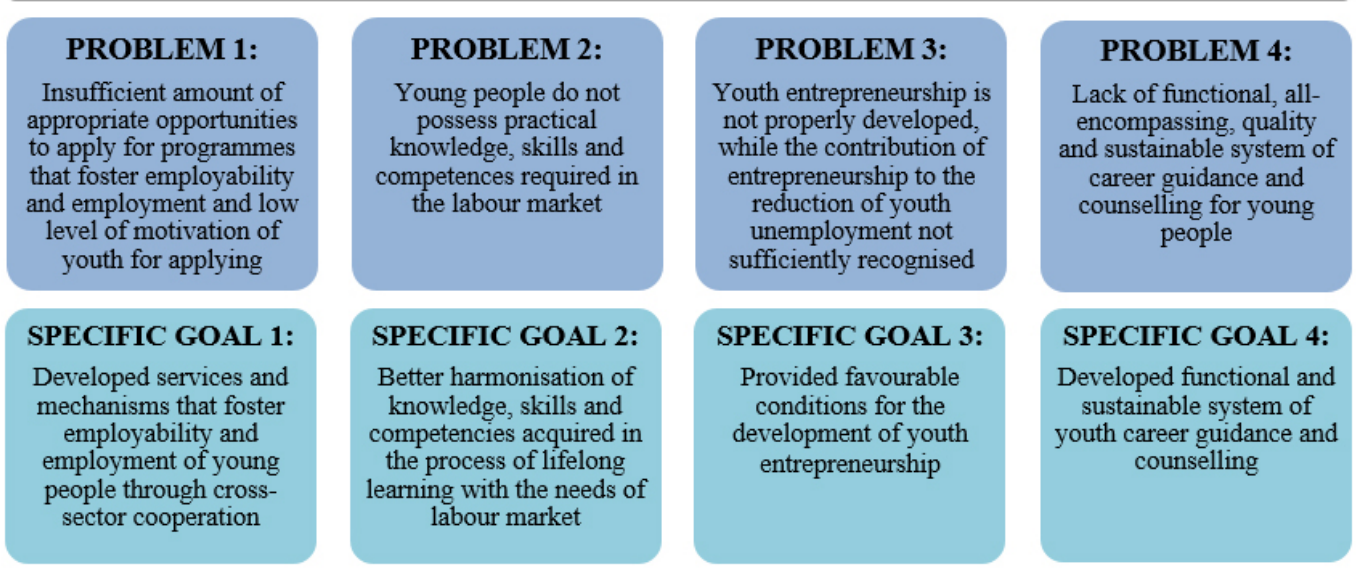

Figure 6: Strategic framework for development of youth employment in Serbia

cial importance in The strategy for support to the development of SME, entrepreneurship and competitiveness from 2015 to 2020, which recognizes six strategic goals:

1. Improvement of business environment,

2. Improvement of the access to sources of finance,

3. Continuous development of human resources,

4. Enhancing the sustainability and competitiveness of MSMEs,

5. Improvement of the access to new markets,

6. Development and promotion of entrepreneurial spirit and encouragement of youth/women entrepreneurship and social entrepreneurship.

As can be noticed, development of youth and women entrepreneurship was identified as one of the strategic goals in development of Serbian MSME sector for the period 2015-2020. Specific goals and measures for achieving this strategic goal were defined in The action plan for the implementation of The strategy for support to the development of SME, entrepreneurship and competitiveness from 2015 to 2020. Strategic framework for the development of youth and women entrepreneurship in Serbia from 2015 to 2020 is presented in Figure 5.

Additionally, National youth strategy 2015-2025, prepared by the Ministry of Youth and Sports (2015) and adopted by the Serbian Government, also points out the importance of youth and women entrepreneurship. The first strategic goal in this document is defined as "Employability and employment of young women and men". It recognizes four main problems and proposes four specific goals, as presented in Figure 6.

Action plans related to The strategy for support to the development of SME, entrepreneurship and compet- itiveness from 2015 to 2020 and National youth strategy 2015-2025 also define concrete activities for the realization of set goals. When complete strategic framework is analyzed, it can be concluded that main problems of young and female entrepreneurs in Serbia have been identified and that certain solutions have been proposed. Some of them are on top level, among strategic and specific goals, and the others are among the activities. This is a huge step for the entrepreneurial environment of youth and women in Serbia and a ground stone for its advance. In order to promote the development of MSME sector, and the strategic framework for the development of youth and women entrepreneurship as its important part, in March 2016 Serbian Government presented the national project "Year of Entrepreneurship 2016". Furthermore, several projects have been initiated, with the goal to identify key industry sectors in which the entrepreneurship of youth and women should be encouraged and supported (Komazec, Todorović and Jevtić, 2016).

However this is just the strategic plan, most of the work still has to be done. In following years the Government must ensure its implementation. The institutions can provide necessary support, but the concrete activities have to be performed by different stakeholders, mostly non-government organizations. The activity stakeholders are on the bottom of the institutional framework which provides the support to MSME sector, so the authorities should identify the appropriate organizations from the youth and women business infrastructure that will execute the operations in accordance with the defined strategic framework. All the activities performed by the activity stakeholders have to be transparent, and the institutional framework must prevent the possible corruption (Krstić et al., 2013). Another 
challenge for the authorities is to define the methods for evaluating the projects executed by the selected activity stakeholders, which is very important for successful implementation of the strategy (Obradović, Petrović and Mihić, 2013). The frameworks for institutional and strategic support to the development of youth and women entrepreneurship in Serbia have been set up, but the improvements can only be achieved by its adequate implementation in following years.

\section{Conclusion}

Authorities in Serbia have recognized the positive aspects that development of MSME sector and entrepreneurship can bring to the economic revitalization of the country. Many authors pointed out social and economic impact of entrepreneurship, which reflects in acceleration of economic activities, job creation and GDP growth. Government support is necessary for full utilization of these benefits. This is particularly significant for developing countries.

Human capital developed at early stage provides the base for future success in career and reduces the possibility of unemployment in older age. This is also important on macro level, since YREs provide benefits for society and develop local communities. Youth entrepreneurship is a successful mechanism for poverty reduction and long term growth of the country. Women entrepreneurship also reduces unemployment and influences economic growth, but female entrepreneurs add new dimension in solving business problems by bringing their personality and values into the company.

Youth and women are two specific categories of entrepreneurs that have to be approached carefully. Unemployment rate in Serbia is highest among young people, while women are generally inferior in business environment comparing to men. Youth and women in Serbia have certain obstacles to start and run own business. Their main problems are poor access to finance, inadequate entrepreneurial skills and lack of specialized support programs. High level of corruption in Serbia strengthens these barriers and causes brain drain. Consequently, they are not ready to risk and found an enterprise. For all these reasons they need a strong backup by policy makers and adequate support of government institutions in order to achieve their entrepreneurial potential.

Most of the issues identified in this research have been recognized in the strategic documents related to development of youth and women entrepreneurship that were adopted by the Serbian Government. The priorities may be discussed, but the measures for solving key problems have been proposed. The only issue that should deserve more attention is the possible corruption. Next challenge for the authorities will be to provide the transparency and to ensure that all the potential users have equal chance. Evaluation of the related projects will be of huge importance for the implementation of defined strategies. Additional task is to identify the adequate activity stakeholders in youth and women business infrastructure that will carry the projects in accordance with the strategic framework.

Future research in this area should be focused on the implementation of strategic frameworks for increasing the employment rate of young people and developing youth and women entrepreneurship in Serbia that were presented and analyzed in this paper, on monitoring the realization of the accompanying action plans, as well as on defining performance indicators and evaluating the effects of the taken measures.

\section{Literature}

Acs, Z. J., Morck, R., \& Yeung, B. (1999). Evolution, community, and the global economy. In Ackermann, Stephen J. (Ed.) Are Small Firms Important? Their Role and Impact, pp. 147-157. Springer Science \& Business Media, USA.

Alam, S. S., Senik, Z. C., \& Jani, F. M. (2012). An Exploratory Study of Women Entrepreneurs in Malaysia: Motivation and Problems. Journal of Management Research, 4(4), 282-297, http://doi.org/10.5296/jmr. v4i4.2377

Audretsch, D. B., Keilbach, M. C., \& Lehmann, E. E. (2006). Entrepreneurship and economic growth. Oxford University Press, UK.

Awogbenle, A. C., \& Iwuamadi, K. C. (2010). Youth unemployment: Entrepreneurship development programme as an intervention mechanism. African Journal of Business Management, 4(6), 831.

Baptista, R. \& Thurik, A. R. (2007). The relationship between entrepreneurship and unemployment: Is Portugal an outlier? Technological Forecasting and Social Change, 74(1), 75-89.

Beck, T., Demirguc-Kunt, A., \& Levine, R. (2005). SMEs, growth, and poverty: cross-country evidence. Journal of economic growth, 10(3), 199-229.

Chigunta, F. J. (2002). Youth entrepreneurship: Meeting the key policy challenges, pp. 1-34. Education Development Center, USA.

Commissioner for Protection of Equality, Republic of Serbia (2013). Regular Annual Report of the Commissioner for Protection of Equality. Retrieved from http://praxis.org.rs/images/praxis downloads/Poverenik $\% 20 \mathrm{za} \% 20 \mathrm{zastitu} \% 20$ ravnopravnosti $\% 20-\% 20$ Izvestaj\%202013.pdf

De Bruin, A., Brush, C. G. \& Welter, F. (2007). Advancing a framework for coherent research on women's entrepreneurship. Entrepreneurship Theory and Practice, 31(3), 323-339.

Duflo, E. (2012). Women, Empowerment, and Economic Development. Journal of Economic Literature, 50(4), 1051-1079, http://doi.org/10.1177/000271629755400 
1009

Erić, D.D., Beraha, I.A., Đuričin, S.O., Kecman, N.Đ. \& Jakšić, B.B. (2012). Financing small and medium-sized enterprises in Serbia. Institute of Economic Sciences, Belgrade, Serbia \& Chamber of Commerce and Industry of Serbia.

Gidarakou, I. (2015). Women's Entrepreneurship in Rural Greece. International Journal of Business and Management, 10(10), 129-142, http://doi.org/10.5539/ ijbm.v10n10p129

Grečić, V. (2010). Serbian scientific diaspora. Institute for International Politics and Economics, Belgrade, Serbia.

Gregg, P. (2001). The Impact of Youth Unemployment on Adult Unemployment in the NCDS. Economic Journal, 111(475), 623-653.

Gregg, P. \& Tominey, E. (2005) The wage scar from male youth unemployment. Labour Economics, 12, 487509.

Jeraj, M., Marič, M., Todorović, I., Čudanov, M. \& Komazec, S. (2015). The role of openness and entrepreneurial curiosity in company's growth. Amfiteatru Economic, 17(38), 371-389. Retrieved from http://www. amfiteatrueconomic.ro/temp/Article 2392.pdf

Kalyani, B., \& Kumar, D. (2011). Motivational factors, entrepreneurship and education: Study with reference to women in SMEs. Far East Journal of Psychology and Business, 3(3), 14-35.

Kokotović, D., Rakić, B. \& Kokotović, T. (2016). Female entrepreneurship: main challenges and the impact of gender gap. In Jaško, O., Marinković, S. (Ed.) Proceedings of the XV International Symposium of Organizational Sciences: Reshaping the Future through Sustainable Business Development and Entrepreneurship. Faculty of Organizational Sciences, Belgrade, Serbia, pp. 504-512.

Komazec, S., Todorović, I. \& Jevtić, M. (2016). Analysis of MSME Ecosystem in Serbia and Identification of Key Strategic Sectors for its Development. In Vrankic, Tomic, D. (Ed.) Economic and Social Development (Book of Proceedings), 13th International Scientific Conference on Economic and Social Development, pp. 112-120. Varazdin Development \& Entrepreneurship Agency, Varazdin, Croatia \& University North, Koprivnica, Croatia.

Kreiser, P. M., Marino, L. D. \& Weaver, K. M. (2002). Assessing the psychometric properties of the entrepreneurial orientation scale: A multi-country analysis. Entrepreneurship Theory and Practice, 26(4), 71-94.

Krstić, G., Schneider, F., Arandarenko, M., Arsić, M., Radulović, B., Ranđelović, S., \& Janković, I. (2013). The shadow economy in Serbia: new findings and recommendations. Foundation for Advancement of Economics and USAID Study, Belgrade, Serbia.

Landstrom, H., Harirchi, G. \& Ăstrom, F. (2012). Entre- preneurship: Exploring the knowledge base. Research Policy, 41(7), 1154-1181.

Ministry of Economy, Republic of Serbia (2014). The strategy for support to the development of SME, entrepreneurship and competitiveness from 2015 to 2020. Retrieved from http://www.rsjp.gov.rs/strateg/50/nac/ Strategija\%2012.12.2014\%20Za\%20press.pdf

Ministry of Economy, Republic of Serbia (2015). The action plan for the implementation of The strategy for support to the development of SME, entrepreneurship and competitiveness from 2015 to 2020. Retrieved from http://www.privreda.gov.rs/wp-content/uploads/2015/06/Akcioni-plan-mala-i-srednja-preduzeca.pdf

Ministry of Labour, Employment, Veteran and Social Policy, Republic of Serbia (2011). The national employment strategy for the period 2011-2020. Official Gazette of Republic of Serbia, 37/2011. Retrieved from http://www.ombudsman.osobesainvaliditetom.rs/attachments/016 Nacionalna\%20strategija\%20za \%20 zaposljavanje.pdf

Ministry of Labour, Employment, Veteran and Social Policy, Republic of Serbia (2009). The national strategy for improving and promoting gender equality in the Republic of Serbia. Official Gazette of Republic of Serbia, 15/2009. Retrieved from http:// www.ombudsman.rodnaravnopravnost.rs/attachments/013 NACIONALNA \%20STRATEGIJA $\% 20$ ZA\%20POBOLJ\%C5\%A0ANJE\%20POLO\%C5\%BDAJA\%20\%C 5\%BDENA \%20I\%20UNAPRE\%C3\%90IVANJE\%20RODNE\%20RAVNOPRAVNOSTI.pdf

Ministry of Labour, Employment, Veteran and Social Policy, Republic of Serbia (2010). The plan of action for the implementation of the national strategy for improving and promoting gender equality 2010-2015. Retrieved from http://www.gendernet.rs/files/dokumenta/ Engleski/Serbian/Plan of Action for the implementation of the National strategy.pdf

Ministry of Youth and Sports, Republic of Serbia (2015). National Youth Strategy 2015-2025. Retrieved from http://www.mos.gov.rs/wp-content/uploads/download-manager-files/NSM\%202015-2025\%20ENGLISH\%20..pdf

Minniti, M., \& Naudé, W. (2010). Introduction: What Do We Know About The Patterns and Determinants of Female Entrepreneurship Across Countries? European Journal of Development Research, 22(3), 277-293, http://doi.org/10.1057/ejdr.2010.17

Mitchelmore, S., \& Rowley, J. (2013). Entrepreneurial competencies of women entrepreneurs pursuing business growth. Journal of Small Business and Enterprise Development, 20(1), 125-142, http://doi. org/10.1108/14626001311298448

Obradović, V., Petrović, D. \& Mihić, M. (2013). Strategic 
Project Management - Project Strategy and Measurement of Success. In Levi Jakšić, M., Barjaktarović Rakočević, S., \& Martić, M. (Ed.) Innovative Management and Firm Performance: An Interdisciplinary Approach, pp. 165-186. Hampshire, UK: Palgrave MacMillan.

Odluka o obrazovanju Saveta za mala i srednja preduzeća, preduzetništvo i konkurentnost [Decision on Establishment of the Council for SME, Entrepreneurship and Competitiveness]. Official Gazette of Republic of Serbia, 43/2015. Retrieved from http://www.slglasnik. info/sr/43-15-05-2015/29124-odluka-o-obrazovanjusaveta-za-mala-i-srednja-preduzeca-preduzetnistvo-ikonkurentnost.html

OECD. (2004). Promoting Entrepreneurship and Innovative SMEs in a Global Economy: Towards a More Responsible and Inclusive Globalisation. OECD Publishing, Paris, France. Retrieved from https://www.oecd. org/cfe/smes/31919590.pdf

OECD (2012). Policy Brief on Youth Entrepreneurship Entrepreneurial Activities in Europe. Publications Office of the European Union, Luxembourg.

Pines, A. M., Lerner, M., \& Schwartz, D. (2010). Gender differences in entrepreneurship. Equality, Diversity and Inclusion: An International Journal, 29, 186-198, http://doi.org/http://dx.doi. org/10.1108/02610151011024493

Płaziak, M., \& Rachwał, T. (2014). The role of entrepreneurship in regional development strategies (based on the Polish National Strategy of Regional Development 2010-2020). Europa XXI, 26, pp. 97-110.

Ratanova, I., Reshina, G., Bruna, S., \& Gross, E. (2014). Development of Small and Medium-Sized Enterprises in Regions of Latvia. Regional Formation and Development Studies, 11(3), 189-198.

Revenga, A., \& Shetty, S. (2012). Empowering women is smart economics. Finance and Development, 49(1), $40-43$.

Rey-Marti, A., Tur Porcar, A., \& Mas-Tur, A. (2015). Linking female entrepreneurs' motivation to business survival. Journal of Business Research, 68(4), 810-814, http://doi.org/10.1016/j.jbusres.2014.11.033

Ryan, C. (2003). Programme Priorities 2003-2006 Youth Enterprise Development. Strategic Paper by the Commonwealth Secretariat. Commonwealth Secretariat, London, UK.

Sarfaraz, L., Faghih, N., \& Majd, A. (2014). The relationship between women entrepreneurship and gender equality. Journal of Global Entrepreneurship Research, 4(6), http://doi.org/10.1186/2251-7316-2-6

Schwartz, E. B. (1976). Entrepreneurship - New female frontier. Journal of Contemporary Business, 5(1), 47-76.

Serbian Union of Employers (2013). Business conditions and development measures. Retrieved from http:// www.poslodavci.rs/eng/

Statistical Office of the Republic of Serbia (2014). Labor Force Survey for 2014. Retrieved from http:// webrzs.stat.gov.rs/WebSite/repository/documents/00/01/71/72/SB-593-bilten_ARS_2014.pdf

Thurik, A. R., Carree, M. A., van Stel, A. \& Audretsch, D. B. (2008). Does self-employment reduce unemployment? Journal of Business Venturing, 23(6), 673-686.

Troha Akanni, M., \& Čepar, Ž. (2015). Impact of Population Ageing on Unemployment and Entrepreneurial Activity: the Case of Slovenia. Organizacija, 48(4), 232-245, http://dx.doi.org/10.1515/orga-2015-0020

Todorović, I., Komazec, S., Jevtić, M. \& Pintar, R. (2016). Guidelines for Strategic Development of MSME Sector in Serbia. In Doucek, P., Novak, A., Paape, B. (Ed.) Sustainable Organization: Proceedings of the 35th International Conference on Organizational Science Development, pp. 1179-1194. Moderna organizacija, Kranj, Slovenia.

UNIDO - United Nations Industrial Development Organization (2016). The IDEA Approach to youth employment and enterprise development. UNIDO inclusive and sustainable industrial development (ISID) working paper series, 2. Retrieved from https://www.unido. org/fileadmin/user_media_upgrade/What_we_do/Topics/Business_investment_and technology_services/ The IDEA Approach to Youth Employment and Enterprise Development new.pdf

Uyar, A. S. \& Deniz, N. (2012). The Perceptions of Entrepreneurs on the Strategic Role of Human Resource Management. Procedia - Social and Behavioral Sciences, 58(0), 914-923.

Vossenberg, S. (2013). Women Entrepreneurship Promotion in Developing Countries: What explains the gender gap in entrepreneurship and how to close it? Maastricht School of Management, Working Paper No. 2013/08. Retrieved from https://www.msm.nl/resources/uploads/2014/02/MSM-WP2013-08.pdf

Vrbanac, M., Milovanović, M. \& Perišić, J. (2016). Women's entrepreneurship - a global perspective and current state in Serbia. In Jaško, O., Marinković, S. (Ed.) Proceedings of the XV International Symposium of Organizational Sciences: Reshaping the Future through Sustainable Business Development and Entrepreneurship. Faculty of Organizational Sciences, Belgrade, Serbia, pp. 522-528.

Wennekers, S. \& Thurik, A.R. (1999). Linking entrepreneurship and economic growth. Small business economics, 13(1), 27-56.

Wilson, K. (2007). Encouraging the internationalization of SMEs in J. Potter, A. Proto (Eds.), Promoting Entrepreneurship in South East Europe: Policies and Tools, 43-66. OECD, Paris, France.

Witbooi, M., \& Ukpere, W. (2011). Indigenous female entrepreneurship : Analytical study on access to finance 
for women entrepreneurs in South Africa. African Journal of Business Management, 5(14), 5646-5657, http://doi.org/10.5897/AJBM10.1161

Zlatkov Cvetković, M. (2015). Women entrepreneurship in Serbia : a qualitative study of the perceived enabling factors for the female entrepreneurship. Swedish University of Agricultural Sciences, Uppsala, Sweden. Retrieved from http://stud.epsilon.slu.se/7637/7/ZlatkovCvetkovi $\%$ C4\%87 M 150219.pdf

Ivan Todorović works as a teaching assistant at the University of Belgrade, Faculty of Organizational Sciences. His research area includes organizational design, restructuring, organizational change, business process management and entrepreneurship. He has participated in more than 15 consulting projects in some of the largest companies from Serbia, as well as in several research projects financed by international institutions like EBRD, UNIDO and USAID. He is a co-author of 3 books and more than 40 articles in international monographs, journals and conference proceedings. From 2011 to 2013 he was a visiting lecturer at the University of Maribor, Faculty of Organizational Sciences, in Slovenia. He was member of the team that won HULT Global Case Challenge 2012 in London, and he won Balkan Case Challenge 2010 in Vienna.

Stefan Komazec is a teaching assistant at the University of Belgrade, Faculty of Organizational Sciences. Currently he teaches "Organizational Theory", "Organizational Design", "Quality Engineering" and "Quality Planning" for undergraduates and several subjects for master students. His major research interests are business process management, standardization, quality management, organizational change and restructuring. As a author or co-author, he has published 3 books and more than 40 articles from these areas in scientific journals and conference proceedings. He was involved in more than 15 business consulting projects in large Serbian companies, and in several research projects under the patronage of international institutions such as UNIDO, EBRD or USAID. He is one of the founders and project leader of international student sport tournament EuroBelgrade, which is organized every year by the Faculty of Organizational Sciences.
Miloš Jevtić works as an associate professor at the Faculty of Organizational Sciences, University of Belgrade. Currently he teaches "Organizational Theory", "Organizational Design" and "Special Event Management" at the undergraduate level, as well as several courses on the master studies. His main fields of interest are organizational design, management control systems, organizational change, leadership and organizational culture. He is an accredited consultant of Human Synergistics for organizational culture and effectiveness. He is author or co-author of more than 50 publications, including books and articles in international monographs, scientific journals and conference proceedings. He was involved in more than 20 commercial and scientific projects from his field of expertise. He is one of the founders of the Belgrade University Rowing Club and its first president.

Vladimir Obradović is a professor at the University of Belgrade, Faculty of Organizational Sciences. For his scientific results, he was awarded the highest scientific rank from Serbian Ministry of Science. He teaches following courses at all levels of education: Management, Project management, Strategic management, Change management, Leadership, etc. He has been engaged as a planning and monitoring expert for Government of Serbia since 2006. He also works as a consultant in several public, non-governmental and profit organizations. As a leader and/or trainer he has participated in a great number of trainings, seminars and other forms of educative programs. He is a director of the International certification of project managers in Serbia and a member of various bodies in International Project Management Association. Also, he is a member of several international associations: SENET, AOM, ILA and CEEMAN.

Miha Marič, Ph.D., is a researcher in the area of leadership, management, and organizational sciences. He is currently employed as an assistant professor at the University of Maribor's Faculty of Organizational Sciences and has a Ph.D. from the Faculty of Economics, University of Ljubljana. His research interests are power, leadership, organizational behavior, HRM, management, organization. As author or co-author, he has published twenty original scientific articles, thirteen professional articles, thirty-five scientific conference contributions, two chapters in monographs and co-authored one scientific monograph, and been an editor and reviewer. He has also participated in research projects and consulting work. 